\title{
Dynamic Underground Stripping Post-Treatment Characterization Plan
}

\author{
Westinghouse Savannah River Company \\ Savannah River Site \\ Aiken, South Carolina 29808
}

Prepared for the United States Department of Energy under Contract No. DE-AC09-96-SR18500 
This document was prepared in conjunction with work accomplished under Contract No.

DE-AC09-96SR18500 with the U.S. Department of Energy.

\section{DISCLAIMER}

This report was prepared as an account of work sponsored by an agency of the United States Government. Neither the United States Government nor any agency thereof, nor any of their employees, makes any warranty, express or implied, or assumes any legal liability or responsibility for the accuracy, completeness, or usefulness of any information, apparatus, product or process disclosed, or represents that its use would not infringe privately owned rights. Reference herein to any specific commercial product, process or service by trade name, trademark, manufacturer, or otherwise does not necessarily constitute or imply its endorsement, recommendation, or favoring by the United States Government or any agency

thereof. The views and opinions of authors expressed herein do not necessarily state or reflect those of the United States Government or any agency thereof.

This report has been reproduced directly from the best available copy.

Available for sale to the public, in paper, from: U.S. Department of Commerce, National Technical Information Service, 5285 Port Royal Road, Springfield, VA 22161, phone: (800)

553-6847, fax: (703) 605-6900, email: orders@ntis.fedworld.gov online ordering: http://www.ntis.gov/ordering.htm

Available electronically at http://www.doe.gov/bridge

Available for a processing fee to U.S. Department of Energy and its contractors, in paper, from: U.S. Department of Energy, Office of Scientific and Technical Information, P.O. Box 62, Oak Ridge, TN 37831-0062, phone: (865 ) 576-8401, fax: (865) 576-5728, email: reports@ adonis.osti.gov 


\section{Dynamic Underground Stripping Post-Treatment Characterization Plan}

March 12, 2001

K. M. Vangelas

With contributions by:

M. E. Denham

C. B. Fliermans

M. A. Heitkamp

B. B. Looney

Westinghouse Savannah River Company

Savannah River Site

Aiken, South Carolina 29808

Prepared for the United States Department of Energy under Contract No. DE-AC09-96-SR18500 


\section{Dynamic Underground Stripping Post-Treatment Characterization Plan}

Table of Contents

Introduction

1.0 Site Description and Layout

2.0 Task Activities

2.1 Sampling Protocols

2.1.1 Sampling Protocol for Microbial Analyses 3

2.1.2 Sampling Protocol for Chemical Analyses 3

2.1.3 Sampling Protocol for Geochemical Analyses 3

$2.2 \quad$ Analyses

2.2.1 Microbial Analyses

2.2.2 Chemical Analyses

2.2.3 Geochemical Analyses

3.0 Task Deliverables

4.0 Task Schedule

5.0 Responsibilities

6.0 Safety

7.0 Quality Assurance

8.0 Regulatory Approval

9.0 References

Figures

Figure 1: Locations of Wells and Thermocouple/ERT Arrays Installed for DUS Remediation 


\section{Introduction}

The A/M-Area of the Savannah River Site is a known area of solvent release to the subsurface. The Solvent Storage Tank Area is an area of documented dense non-aqueous phase liquids (DNAPL) in the subsurface. June 30, 2000 a remediation using the Dynamic Underground Stripping (DUS) treatment technology commenced. This technology injects steam into the subsurface through a series of injection wells located within the treatment zone. The steam is pulled through the subsurface to an extraction well where it is removed. The heating of the subsurface causes the DNAPL present to be volatilized and removed through the extraction well. The temperature of the subsurface is brought to a temperature of approximately $69^{\circ} \mathrm{C}\left(157^{\circ} \mathrm{F}\right)$. The steam injection began June 30, 2000 and is ongoing in March 2001. In heating the subsurface to this temperature, the indigenous microbial community in the treatment zone will be altered. It is also possible that geo-chemical parameters may be altered due to the prolonged heating of the subsurface. Injection of steam into the subsurface can cause inorganic geochemical reactions. Denham (2000) outlined three potential effects of these reactions:

1) dissolution of silica caused by increased subsurface temperature,

2) dissolution of minerals by acidic conditions associated with hydrous pyrolysis,

3) elevated concentrations of metals of regulatory concern (e.g. $\mathrm{Cr}, \mathrm{Cu}$, and $\mathrm{U}$ ) caused by acidic and oxidizing conditions associated with hydrous pyrolysis.

Post-treatment characterization will be conducted to evaluate three items: 1) removal of PCE and TCE from the treatment zone; 2) repopulation of the microbial community; and 3) effects of the treatment on the geochemical properties of the treatment zone.

Sampling identified in this characterization plan begins after steam injection has been completed.

\subsection{Site Description and Layout}

The treatment site is a $100 \mathrm{ft}$ by $100 \mathrm{ft}$ area that surrounds the Solvent Storage Tank Pad, located west of building 321-M. The treatment site is $165 \mathrm{ft}$ deep. The site is located within an inactive industrial area. The Solvent Storage Tank area was put into operation in 1957. This facility consisted of a 17,000 gallon storage tank with associated piping and equipment necessary to off-load solvent from rail-cars to the storage tank and to distribute solvent to the other process facilities in the M-Area and across the SRS. This facility served as the primary point for the storage and distribution of solvent in the M-Area except for the period between 1962 and 1970, during which PCE was introduced into the 313-M process and would have required local storage. According to Marine and Bledsoe (1984), numerous undocumented spills and leaks occurred in the vicinity of the solvent storage tank from off-loading the railroad cars. At the 321-M Solvent Storage Tank one spill of significance is reported to have occurred in October 1975. A cracked ceramic seal on a transfer pump resulted in an estimated 1,200 gallons of PCE being released to the environmental. The incident report states that there was no evidence of PCE puddling on the ground.

Characterization of this area was performed by CH2M Hill in 1990 (CH2M Hill, 1990) and resulted in a total of 28 shallow soil gas samples being taken around the tanks and railroad tracks. TCE was detected in approximately $67 \%$ of the samples, with concentrations ranging from 0.11 to 4,200 parts per billion in vapor (ppbv). PCE was detected in all of the samples, with concentrations ranging from 0.12 to 570,000 ppbv. TCA was detected in all but one of the samples, with concentrations ranging from 0.90 to 3,000 ppbv. Four soil borings (SRM-101-B through SRM-104-B) were drilled in the immediate vicinity of the solvent storage area. Significant concentrations of TCE and PCE were detected in soil samples collected from numerous intervals within each of the four borings. The overall highest concentrations of solvents 
were detected in soil samples collected from the 14 to 35 foot depth with PCE detected at concentrations as high as 3,000 parts per million (ppm). Significant concentrations ranged in depth from $5 \mathrm{ft}$ to the top of the water table (approximately $135 \mathrm{ft}$ bgs) at each boring. As a result of this data an active soil vapor extraction (SVE) system was installed and began operation in 1995. The SVE system has removed 28,238 pounds of solvent from the vadose zone in this area. Characterization investigations from 1992 through 1997 were conducted to evaluate the lateral extent of (primary emphasis) and change in vertical contaminant distribution (secondary emphasis) (WSRC-RP-98-00146). The results of the soil gas and soil plug samples indicated very high soil concentrations (>1000 parts per million weight (ppmw)) at shallow depths ( $<50 \mathrm{ft} \mathrm{bgs})$ and consisting primarily of PCE. This shallow contamination is confined to the immediate vicinity of the tanks on the eastern and southern sides of the pad. The shallow concentrations showed very little change since the CH2M Hill report of 1990. Concentrations less than 10 ppmw were observed down to the water table where TCE predominates. Coring in 1999 indicated that DNAPL concentrations are still present in pockets within the shallow vadose zone.

Deployment of the DUS remediation technology involved installation of 3 injection well clusters, 1 extraction well and 13 locations for thermocouple and ERT monitors. The layout of these wells and thermocouple/ERT locations are shown on Figure 1.

\subsection{Task Activities}

Soil sampling will concentrate on chemical contaminants, microbial communities, and geochemical parameters. Borings will be drilled using hollow-stem auger in the vadose zone and rotosonic drilling below the water table. This is necessary to minimize the amount of water entering the vadose zone due to the drilling method. This water will have the effect of flushing microbes from the area to be sampled. It will also affect the natural rate of cooling.

If during the sampling events, the cores being collected are within the zone of capture of an active soil vapor extraction (SVE) system, SRTC will require the SVE system be turned off during the sampling event. This is necessary to minimize any outside influences on the samples.

Sampling locations will concentrate on the center of the treatment area (i.e., that area that reached the highest temperature), the periphery of the treatment area and a control location outside the treatment area. Sampling locations for microbial analyses will focus on the density, distribution and biodiversity of soil microorganisms across the test cell. Sampling locations for the chemical data will focus on 1) evaluation of whether the treatment system pushed contaminants outside the treatment area and 2) evaluation of removal of contaminants within the treatment area. Sampling locations for the geo-chemical data will focus on heated versus unheated locations and lithified versus unlithified portions of the cores.

All microbial and chemical samples will be analyzed by SRTC personnel. Petrographic thin-sections for optical microscopy will be prepared by an off-site vendor. The geo-chemical analyses will be conducted by SRTC personnel.

As the sampling is based on temperature recovery to ambient, bi-weekly measurements will be taken from the thermocouples left in place at the DUS site, initially. This frequency will decrease if the subsurface temperature change is not measurable. For purposes of planning we will assume sampling of the thermocouples bi-weekly for a period of 6 months, then decreasing to once per month for the remaining 18 months. 


\subsection{Sampling Protocols}

\subsubsection{Sampling Protocol for Microbial Analyses}

Cores for microbial analyses should be taken with Shelby tubes or similar technology so that the sediment core can be extruded and sampled to maintain microbial integrity. Microbial sampling is best done in the sandy regions of the core since microbial analyses are more easily facilitated.

Using Shelby or Phosphate barrel sampling tubes (Phelps, et al., 1989) the areas of sampling are estimated to be in the 65-85 foot depth; the 110-130 foot depth and the $145-155$ foot depth. The exact depths will be selected in the field. Samples will be extruded and the inner core processed through extraction mechanisms as previously described (Fliermans, 1989; Hazen et al., 1991).

\subsubsection{Sampling Protocol for Chemical Analyses}

Samples for chemical data will be collected on 2 foot intervals from surface to total depth. Duplicates will be collected and analyzed for all samples.

Sediment samples are collected by taking a 2 cc plug sample from the center of the core using a modified plastic syringe. The plug is transferred to a $22 \mathrm{ml}$ vial containing $5 \mathrm{ml}$ of nano-pure water and the vial is sealed with a crimped septum top for later head space analysis. All samples are stored at $4^{\circ} \mathrm{C}$ until analysis.

\subsubsection{Sampling Protocol for Geochemical Analyses}

Each major lithologic type in a soil boring will be sampled. In addition, if there are lithified portions of the boring they will be sampled for comparison to unlithified samples.

Soil will be sampled from two of the soil borings ( 1 heated and 1 unheated) used in the post-test microbiological sampling. For each sample approximately 0.5 kilograms of soil will be taken with a stainless steel spatula. Each sample will be split into 3 portions -2 for analysis and one for archiving.

\subsection{Analyses}

\subsubsection{Microbial Analyses}

Samples will be processed for total mesophilic and thermophilic bacteria by plate count technology using PTYG and 1\% PTYG media as previously described. Samples will be incubated at thermophilic, mesophilic and psychrophilic temperatures to determine the relative abundance of each group of organisms. Total direct microbial density and activity analyses will be measured using a combination of FITC, AODC, and Live/Dead ${ }^{\circledR}$ analyses. Additionally the major serogroups of Legionella pneumophila will be analyzed. Legionella is thermophilic-type bacterium that has shown a stimulation response in the past to moderate heating excursions of subsurface soils.

The data will be expressed as the number of total bacteria per gram of soil, number of bacteria in each thermophilic regime per gram of soil, the density of the total direct number of bacteria per gram of soil; and the total number of active bacteria by direct microscopy examination. The results from these data will provide information as to whether the heating completely destroys the bacterial population and their activity; the affect of the heating on an environmental pathogen that is thermophilic-like in its physiology; and whether there is a stimulation of the microbial populations on the outer edges of the active heating zones. 


\subsubsection{Chemical Analyses}

Each sample is weighed and then analyzed on a gas chromatograph (GC) equipped with flame ionization detector (FID) and electron capture detector (ECD). Equilibrated headspace gas is sub-sampled and transferred to the GC using an automated head space sampler. Equivalent water concentrations are calculated using the appropriate detector (ECD for low concentrations, FID for high concentrations). Mass soil concentrations (ppb, $\mu \mathrm{g} / \mathrm{kg}$ ) are calculated based on an equal head space volume from $7.5 \mathrm{ml}$ of water standards and approximately $7.5 \mathrm{ml}$ of water/soil matrix and are corrected for the mass difference between soil and water. The gas chromatograph is calibrated using certified solvent mixtures in methanol diluted to specific concentrations. Standard concentrations used are 3, 5, 10, 50, 250, 500, and $1000 \mathrm{ppb}(\mu \mathrm{g} / \mathrm{l})$. The standards are analyzed TCE and PCE.

\subsubsection{Geochemical Analyses}

Two types of analyses will be conducted - one for scanning electron microscopy (SEM) and one for optical microscopy. Petrographic thin-sections for optical microscopy will be prepared by an off-site vendor. Optical microscopy will be used to examine the samples for gross changes in grain morphology and pore filling materials. SEM will be used to examine the surface of mineral grains for evidence of dissolution. These analyses will be qualitative comparisons of heated and unheated samples and are useful for full understanding of the water chemistry data.

\subsection{Task Deliverables}

Upon demobilization from the treatment area by the DUS vendor, SRTC personnel will make a field visit to select locations for the collection of the first round of soil cores. This information will be provided to ER for agreement. The locations and a sample location map will be incorporated into the technical report prepared at the completion of this post-test characterization effort to document the locations. This process will be repeated for the subsequent rounds of sampling.

A draft technical report will be prepared detailing the results of the post-test characterization at the DUS remediation site. The draft report will be submitted to ER for comments. ER comments will be incorporated and the final report submitted to ER within one month of receipt of comments.

\subsection{Task Schedule}

Field activities will be spaced over a period not to extend past 24 months. The exact scheduling will be dependent on temperature recovery in the subsurface at the DUS remediation site. This temperature dependence for the sampling is driven by the microbial sampling needs.

Sampling Event 1: Samples will be collected when the soil temperature at the center of the treatment area is approximately $70^{\circ} \mathrm{C}\left(157^{\circ} \mathrm{F}\right)$. This first round of samples will be for microbial and geochemical parameters. Soils will be at their peak temperature at this time. This sampling round should occur shortly after the DUS vendor demobilizes from SRS. The samples for chemical data at the outside edge of the treatment area may or may not be taken at this time, dependent on the results of the DUS vendors last temperature profile for the treatment area. A control core, outside the treatment zone, will be collected at this time.

Sampling Event 2: Samples will be collected when the soil temperature at the center of the treatment area is approximately $50^{\circ} \mathrm{C}\left(122^{\circ} \mathrm{F}\right)$. This round of samples will be for microbial analyses. If the samples for chemical data at the outside edge of the treatment area were not collected in the first sampling event, they will be collected during this second event. 
Sampling Event 3: Samples will be collected at a temperature below $35^{\circ} \mathrm{C}\left(95^{\circ} \mathrm{F}\right)$ or at the 22 month period of the 24 month period of performance. At this time, an additional round of geo-chemical samples will be collected. Dependent on the results of the second round of data, a third round of microbial samples may be collected.

As the sampling is based on temperature recovery to ambient, bi-weekly measurements will be taken from the thermocouples left in place at the DUS site, initially. This frequency will decrease if the subsurface temperature change is not measurable. For purposes of planning we will assume sampling of the thermocouples bi-weekly for a period of 6 months, then decreasing to once per month for the remaining 18 months.

\subsection{Responsibilities}

Tom Kmetz, ERD customer

Jim Kupar, ERD Technical lead

Karen Vangelas, SRTC lead

Brian Looney, SRTC alternate lead

Johnny Simmons, field technician

\subsection{Safety}

All activities will be performed in accordance with WSRC Manual 8Q, "Employee Safety" and WSRC Manual 4Q "Industrial Hygiene". Protective equipment will be as stated on the Work Clearance Permit.

\subsection{Quality Assurance}

This project has been designated as a scoping level research and development activity as defined by WSRC 1Q Procedure 2-3, "Control of Research and Development Activities" and Procedure L1 - 7.10 Rev. 2 "Control of Technical Work".

Laboratory analysis of TCE and PCE by GC will be performed in accordance with WSRC Manual L14.1 Procedure 2-106 (rev. 1), "Procedure for the Operation and Calibration of Gas Chromatographs Used for the Analysis of Gas Phase Samples". Geo-chemical analyses performed by ADS will follow the operating procedures of the SRTC/Analytical Development Section. Microbiological analyses performed by SRTC/EBS will follow the operating instructions of the SRTC/Environmental Biotechnology Section.

\subsection{Regulatory Approval}

Regulatory approval is not required for this work scope.

\subsection{References}

Denham, M., 2000, Possible Geochemical Interactions Associated with DUS Operations, SRT-EST-200000170, memorandum dated March 24, 2000 to J. Kupar.

Fliermans, C. B. 1989. Microbial life in the terrestrial subsurface of southeastern coastal plain sediments. Hazardous Waste \& Hazardous Materials $\underline{6}: 155-175$. 
Hazen, T.C., L. Jimenez, G. Lopez de Victoria and C. B. Fliermans. 1991. Comparison of Bacteria from Water and Sediment Cores in Terrestrial Subsurface, Microbial Ecology 22:293-304.

Phelps, T. J., C. B. Fliermans, T. Garland, S. M. Pfiffner and D. C White. 1989. Recovery of deep subsurface material for microbiological studies. Journal of Microbiological Methods 9: 267-279. 


\section{As-Built Well Locations}

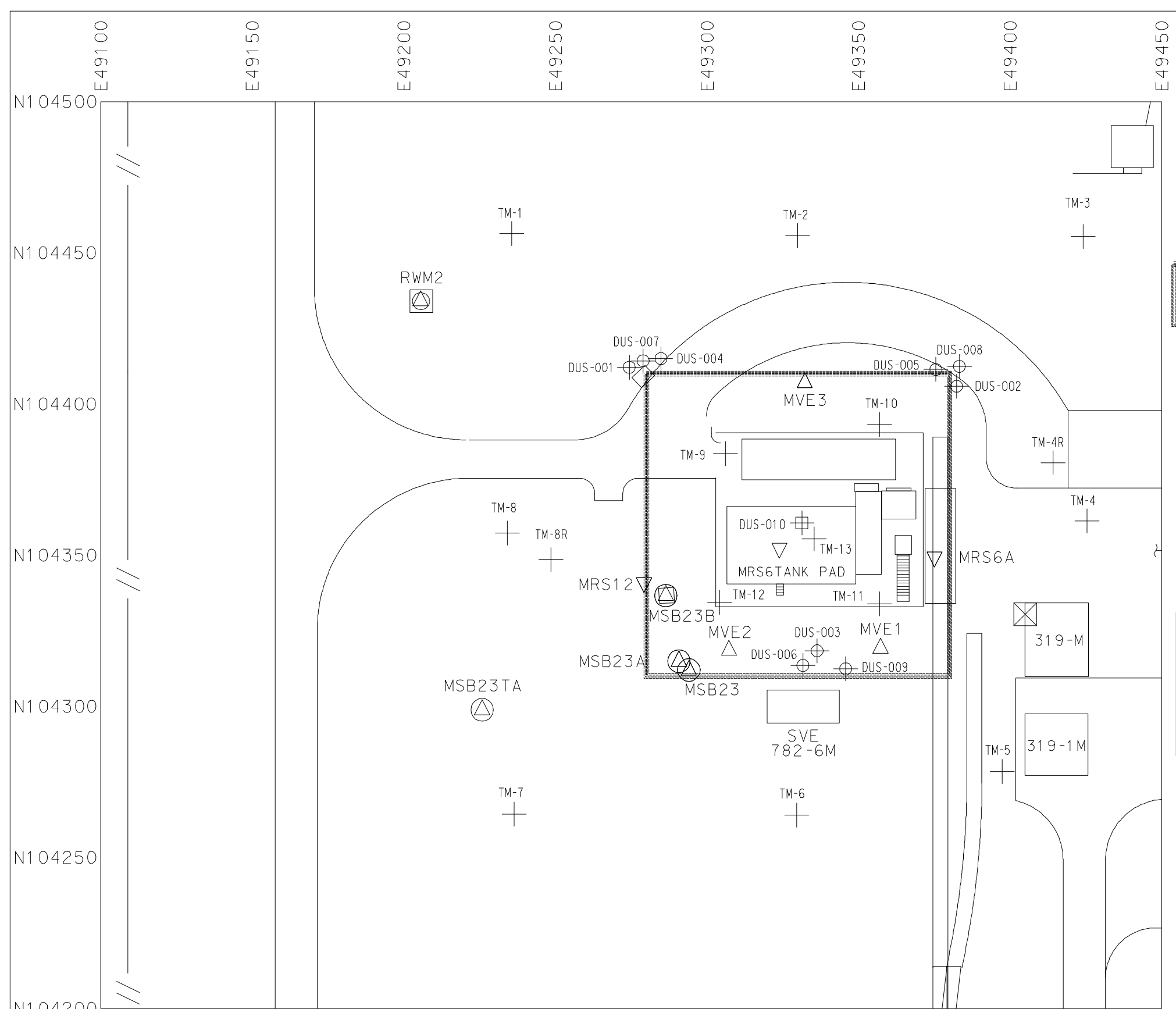

Figure 1: Locations of Wells and Thermocouple/ERT Arrays Installed for DUS Remediation
LEGEND

$\triangle$ EXISTING SOIL VAPOR

(1) MONITOR WELL

A] AIR STRIPPER TIE-IN POINT

$\triangle$ ELECTRICAL TIE-IN POINT

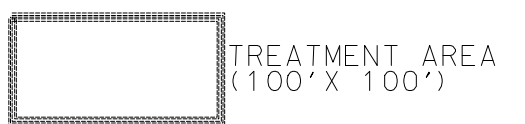

INJECTION WELL

中 EXTRACtion WelL

$+_{\substack{\text { THERMAL MONI TORING } \\ \text { LOCATION }}}$

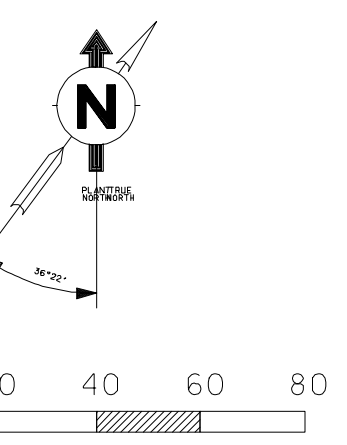

$\begin{array}{llll}0 & 20 & 40 \quad 60 \quad 80 \\ 0\end{array}$

SCALE: FEET

\begin{tabular}{|l|c|l|c|}
\hline WELL \# & NORTHINGS & EASTINGS & $\begin{array}{c}\text { TOP OF } \\
\text { SCREEN } \\
\text { (FT. BLS })\end{array}$ \\
\hline DUS-001 & 104412.1361 & 49274.3923 & 50 \\
\hline DUS-002 & 104405.8501 & 49382.3849 & 50 \\
\hline DUS-003 & 104318.3383 & 49336.3042 & 50 \\
\hline DUS-004R & 104380.5980 & 49414.1609 & 110 \\
\hline DUS-005 & 104411.3914 & 49375.4416 & 110 \\
\hline DUS-006 & 104313.4985 & 49331.5855 & 110 \\
\hline DUS-007 & 104414.2475 & 49278.9029 & 150 \\
\hline DUS-008 & 104412.4093 & 49383.2832 & 150 \\
\hline DUS-009 & 104312.3412 & 49345.6992 & 150 \\
\hline DUS-010 & 104393.2336 & 49356.8928 & 20 \\
\hline
\end{tabular}

\begin{tabular}{|c|c|c|}
\hline ERT & NORTHINGS & EASTINGS \\
\hline TM-1 & 104456.3405 & 49235.5037 \\
\hline$T M-2$ & 104455.6610 & 49329.8491 \\
\hline$T M-3$ & 104455.4224 & 49423.9995 \\
\hline$T M-4 R$ & 104380.5980 & 49414.1609 \\
\hline$T M-5$ & 104278.4435 & 49397.3652 \\
\hline$T M-6$ & 104263.9143 & 49329.5578 \\
\hline$T M-7$ & 104264.2824 & 49236.3233 \\
\hline$T M-8 R$ & 104348.4024 & 49248.5106 \\
\hline$T M-9$ & 104383.5622 & 49306.0912 \\
\hline$T M-10$ & 104393.2336 & 49356.8928 \\
\hline$T M-11$ & 104333.8998 & 49356.8735 \\
\hline$T M-12$ & 104334.3334 & 49304.1836 \\
\hline$T M-13$ & 104355.3998 & 49331.5893 \\
\hline
\end{tabular}

